\title{
UPAYA BADAN NARKOTIKA NASIONAL (BNN) KOTA KEDIRI DALAM MENANGGULANGI PENYALAHGUNAAN NARKOBA
}

\author{
Aulia Zulfa ${ }^{1)}$, Teguh Pramono ${ }^{2)}$. \\ 1)Prodi Administrasi Publik, Fakultas Sosial dan Politik, Universitas Kadiri, Indonesia \\ 2)Prodi Administrasi Publik, Fakultas Sosial dan Politik, Universitas Kadiri, Indonesia \\ *Email Korespondensi: tghpram@unik.ac.id
}

\begin{abstract}
Abstrak
Penelitian ini bertujuan untuk mendeskripsikan dan menganalisis upaya Badan Narkotika Nasional dalam menanggulangi penyalahgunaan narkoba di wilayah Kota Kediri, serta mendeskripsikan dan menganalisis faktor yang mendukung atau menghambat upaya Badan Narkotika Nasional untuk menanggulangi penyalahgunaan narkoba di wilayah Kota Kediri. Pendekatan yang digunakan dalam penelitian ini adalah pendekatan kualitatif. Narasumber dalam penelitian berjumlah 5 orang. Teknik pengumpulan data dalam penelitian ini meliputi wawancara dan observasi yang ditulis dalam catatan lapangan. Keabsahan data dikaji dengan 2 metode yakni trianggulasi dan ketekunan pengamatan. Sementara itu, teknik analisis data mengacu pada Creswell. Hasil yang diperoleh yakni informasi bahwa BNN Kota Kediri mempunyai komitmen bersama dengan berbagai instansi lainnya guna menekan angka penyalahguna narkoba dengan dibentuknya berbagai program kegiatan. Upaya sosialisasi dilakukan dengan memberikan materi Pemberantasan Penyalahgunaan dan Peredaran Gelap Narkoba pada palajar, pekerja dan berbagai kelompok masyarakat serta menyampaikannya pada acara radio maupun televisi local setempat. Pembentukan kelurahan bersih narkoba (bersinar) dan penerbitan Surat Keterangan Hasil Pemeriksaan Narkotika merupakan program dariupaya pencegahan. Dalam menjalankan tugas, BNN tidak menemukan hambatan yang signifikan. Hambatan yang ditemui hanya seputar tantangan mengelola anggaran dan beban moral karena menangkap warga sendiri yang terlibat narkoba.
\end{abstract}

Kata kunci: BNN; hambatan; pencegahan; pemberantasan; sosialisasi

\begin{abstract}
This study aims to describe and analyze the efforts of the National Narcotics Agency in tackling drug abuse in the City of Kediri, as well as to describe and analyze the factors that support or hinder the efforts of the National Narcotics Agency to tackle drug abuse in the City of Kediri. The approach used in this study is qualitative. Resource persons in the study amounted to 5 people. Data collection techniques in this study include interviews and observations written in field notes. The validity of the data was studied using 2 methods, namely triangulation and observation persistence. Meanwhile, the data analysis technique refers to Creswell. The results obtained are information that the Kediri City BNN has a joint commitment with various other agencies to reduce the number of drug abusers by establishing various activity programs. Socialization efforts are carried out by providing material on the Eradication of Abuse and Illicit Narcotics to students, workers and various community groups and conveying it on local local radio and television programs. The establishment of a drug-free (shining) urban village and the issuance of a Narcotics Examination Result Certificate are programs of prevention efforts. In carrying out their duties,
\end{abstract}


BNN did not find significant obstacles. The only obstacles that were encountered were the challenges of managing the budget and the moral burden of catching the people who were involved in drugs.

Keywords: BNN; barriers; prevention; eradication; socialization.

\section{PENDAHULUAN}

Indonesia merupakan salah satu negara yang memiliki kepadatan penduduk tertinggi ke empat di dunia. Berbagai media internasional baru baru ini bahkan memprediksi bahwa Indonesia akan mampu bersaing dengan negara papan atas suatu saat nanti. Hal ini didasarkan pada fakta menarik bahwa selain peningkatan ekonomi, jumlah penduduk muda di Indonesia akan mengalami dominasi yang tinggi dalam beberapa tahun ke depan. Pertumbuhan yang sangat pesat ini harus senantiasa dikawal dari adanya berbagai ancaman yang senantiasa membayangi rusaknya potensi besar dari sektor sumberdaya manusia yang melimpah ini.

Salah satu faktor yang dapat merusak masa depan pemuda bangsa ini yakni berupa penyalahgunaan narkoba. Narkoba merupakan singkatan dari narkotika, psikotropika dan bahan/zat aditif lainnya. Narkoba menurut Undang-Undang (UU) Nomor 22 Tahun 1997 adalah sebuah zat atau obat berasal dari tanaman atau bukan dari tanaman baik yang berbahan sintetis maupun semi sintetis yang dapat menyebabkan hilangnya rasa, perubahan/penurunan kesadaran dan dapat menimbulkan ketergantungan. Narkoba sejatinya tidak dilarang penggunaannya terutama jika berkaitan dengan ilmu medis, namun penyalahgunaan berbagai obat jenis ini jika dikonsumsi oleh masyarakat akan sangat fatal terutama bagi kesehatan fisik dan mental dalam jangka panjang.

Maraknya penggunaan yang tidak sah dari berbagai macam jenis narkotika dan psikotropika di negeri ini kian serius dan mengkhawatirkan serta tidak bisa dianggap remeh. Berdasarkan hasil survei yang dilakukan oleh Badan Narkotika Nasional (BNN) bekerja sama dengan Lembaga Ilmu Pengetahuan Indonesia (LIPI), sebesar 2,3 juta pelajar dan mahasiswa di Indonesia pernah mengkonsumsi narkoba. Tentu angka yang sangat besar ini sungguh memberikan kabar yang miris, manakala di era milenial sekarang ini peredaran narkoba sudah sangat meluas, bahkan hingga menjangkau para remaja. Oleh 
karena itu, pengawasan terhadap peredaran narkoba ilegal ini harus segera gencar di tingkatkan.

Dalam rangka mencegah dan memberantas penyalahgunaan narkoba, pemerintah melalui Peraturan Presiden (Perpres) Nomor 83 Tahun 2007 membentuk sebuah kelembagaan bernama Badan Narkotika Nasional (BNN). Lembaga ini meliputi Badan Narkotika Nasional, Badan Narkotika Daerah dan Badan Narkotika Kabupaten/Kota. Dalam Undang Undang (UU) Nomor 35 Tahun 2009 tentang narkotika, BNN merupakan Lembaga Pemerintah Non Kementerian (LPNK) yang berkedudukan dan bertanggung jawab secara langsung kepada presiden. Sebagai antisipasi dalam meluasnya peredaran narkoba, BNN diharapkan mampu memberikan dorongan kepada para masyarakat agar terbebas dari pengaruh negatif narkoba tersebut. Maka dari itu, BNN harus mengambil peran yang signifikan dan berkolaborasi dengan para penegak hukum maupun masyarakat untuk memberantas segala bentuk peredaran narkoba termasuk di wilayah kota/kabupaten.

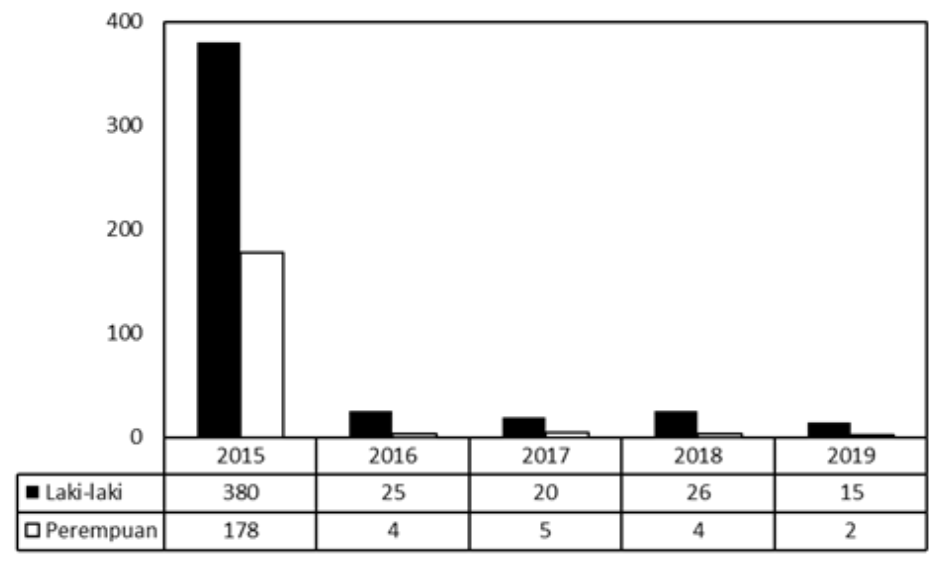

Gambar 1. Jumlah Pecandu Narkoba di Kota Kediri Dalam 5 Tahun Terakhir Yang Dirilis Oleh Badan Narkotika Nasional.

Sumber: Data Badan Narkotika Nasional Kota Kediri, 2019

Grafik diatas menunjukkan data klien pecandu narkoba Kota Kediri dari tahun 2015 hingga tahun 2019. Secara umum, jumlah pecandu penyalahgunaan narkoba di Kota Kediri telah mengalami penurunan yang sangat signifikan dari yang semula mempunyai jumlah total sebesar 558 orang pada tahun 2015 hingga hanya berjumlah 17 orang pada tahun 2019. Jumlah klien yang terdata ini sangat menggembirakan bagi kinerja BNN di 
Kota Kediri dan layak diberikan apresiasi, terlebih bahwa pengguna dari kalangan perempuan telah berhasil ditekan hingga menunjukkan hanya 2 orang pengguna narkoba pada tahun terakhir. Walaupun demikian, dari tahun 2017 yang semula hanya berjumlah 25 orang mengalami peningkatan kembali di tahun 2018 menjadi 29 orang.

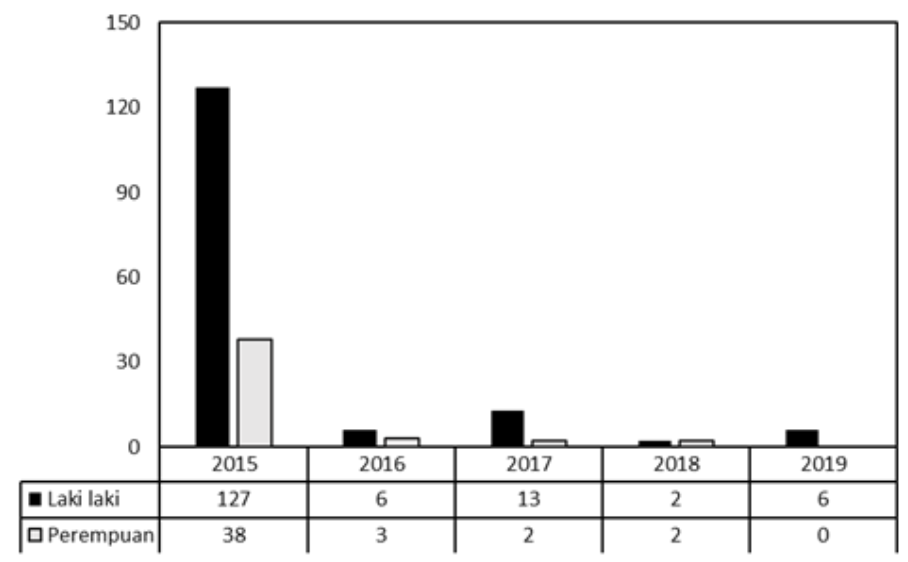

Gambar 2. Jumlah Klien Badan Narkotika Nasional (BNN) Kota Kediri Dalam 5 Tahun Terakhir.

Sumber: Data Badan Narkotika Nasional Kota Kediri, 2019

Rendahnya jumlah klien dari BNN seperti yang ditunjukkan oleh grafik diatas manunjukkan bahwa korban penyalahgunaan narkoba masih berpeluang bertambah sebab kinerja BNN belum sepenuhnya maksimal. Maka dari itu, hambatan teknis maupun nonteknis dalam menanggulanginya harus diminimalisir dan melibatkan beberapa pihak terkait agar kinerja BNN lebih efektif.

\section{TINJAUAN PUSTAKA}

Penelitian terdahulu menjadi suatu acuan dalam melakukan penelitian dan mengangkat beberapa penelitian sebagai bahan referensi. Berikut beberapa penelitian terdahulu yang merupakan kumpulan karya ilmiah terkait guna menunjang keberhasilan penelitian ini:

(Sinaga, 2019) Melakukan penelitian terkait kinerja BNN. Karya tulisnya berjudul Peranan Badan Narkotika Nasional (BNN) Provinsi Lampung Dalam 
Menanggulangi Penyalahgunaan Narkoba. Penelitian ini menggunakan metode penelitian kualitatif dengan jumlah infornan sebanyak 3 orang yang dilakukan berdasarkan wawancara secara mendalam. Berdasarkan hasil penelitian, BNN Provinsi Lampung berperan normatif dan ideal dalam kasus terkait.

Penelitian serupa juga pernah dilakukan oleh (Laksono, 2015). Dalam karya tulisnya yang berjudul Upaya Penanggulangan Peredaran dan Penyalahgunaan Narkotika di Wilayah Pedesaan (Studi di Badan Narkotika Nasional Kabupaten Kediri dan Satuan Reserse Narkoba Kepolisian Resort Kediri), ia berhasil menempuh sarjana hukum di Universitas Brawijaya. Metode yang digunakan adalah yuridis sosiologis. Hasil penelitian menunjukkan bahwa beberapa hambatan ditemui seperti penjara kurang memadai, kesadaran lapor diri yang kurang serta wewenang BNN daerah yang terbatas.

Pada Tahun 2013, melalui karya tulisnya yang berjudul Upaya Badan Narkotika Dalam Menanggulangi Penyalahgunaan Variasi Tanaman \& Zat Yang Mengandung Efek Narkotika (Studi Kasus Di Kantor Badan Narkotika Nasional Kota Malang, Leksana mengungkapkan bahwa upaya penanggulangan oleh BNN Kota Malang terdapat dua upaya yaitu upaya preventif (pencegahan) dan upaya represif (penindakan) serta juga kendala apa saja yang dialami BNN Kota malang dalam upaya menanggulangi penyalahgunaan narkoba. Metode yang digunakan adalah yuridis kriminologis. Merupakan penelitian yang dilakukan oleh (Leksana, 2013).

(Menthan, 2013) juga memberikan gambaran bahwa peran Badan Narkotika Nasional Kota Samarinda dalam menanggulangi masalah narkoba di kalangan remajaa sudah sesuai dengan yang dijalankan BNN Kota Samarinda dengan cara melihat faktafakta dilapangan. Data diperoleh dengan menggunakan analisis deskriptif kualitatif melalui karya tulisnya yang berjudul Peranan Badan Narkotika Nasional Kota Samarinda dalam Penanggulangan Masalah Narkoba di Kalangan Remaja Kota Samarinda.

Dalam karya tulisnya yang berjudul Kendala dan Upaya Rehabilitasi Bagi Pecandu Narkotika oleh Badan Narktika Nasional Provinsi (BNNP) Yogyakarta, (Felicia, 2015) mengemukakan bahwa implementasi rehabilitasi sudah sangat baik namun beberapa kasus masih ditemui rehabilitasi secara paksa akibat pecandu narkoba yang diluar kendali. Metode yang digunakan adalah legal normatif. 


\section{METODE PENELITIAN}

Pendekatan penelitian yang digunakan penelitian ini adalah pendekatan kualitatif. Menurut (Strauss \& Corbin, 2003) yang dimaksud dengan penelitian kualitatif adalah jenis penelitian yang menghasilkan penemuan-penemuan yang tidak dapat dicapai (diperoleh) dengan menggunakan prosedur-prosedur statistic atau cara-cara lain dari kuantifikasi (pengukuran). Lokasi penelitian ini di tetapkan di Kota Kediri dengan pertimbangan berdasarkan data BNN Kota Kediri kasus penyalahgunaan narkoba di Kota Kediri dalam kurun waktu lima (5) tahun terakhir menunjukkan penurunan yang signifikan. Sumber data dalam penelitian ini adalah semua pegawai BNN Kota Kediri sebagai pihak yang berusaha atau untuk menurunkan penyalahgunaan narkoba. Untuk menentukan informan kunci digunakan teknik purposive sampling. Teknik ini merupakan teknik untuk menentukan sampel penelitian dengan beberapa pertimbangan tertentu yang bertujuan agar data yang diperoleh nantinya bisa lebih representative (Sugiono, 2016) Teknik analisis data yang akan digunakan mengacu pada Creswell (2015) dalam (Sugiono, 2016).

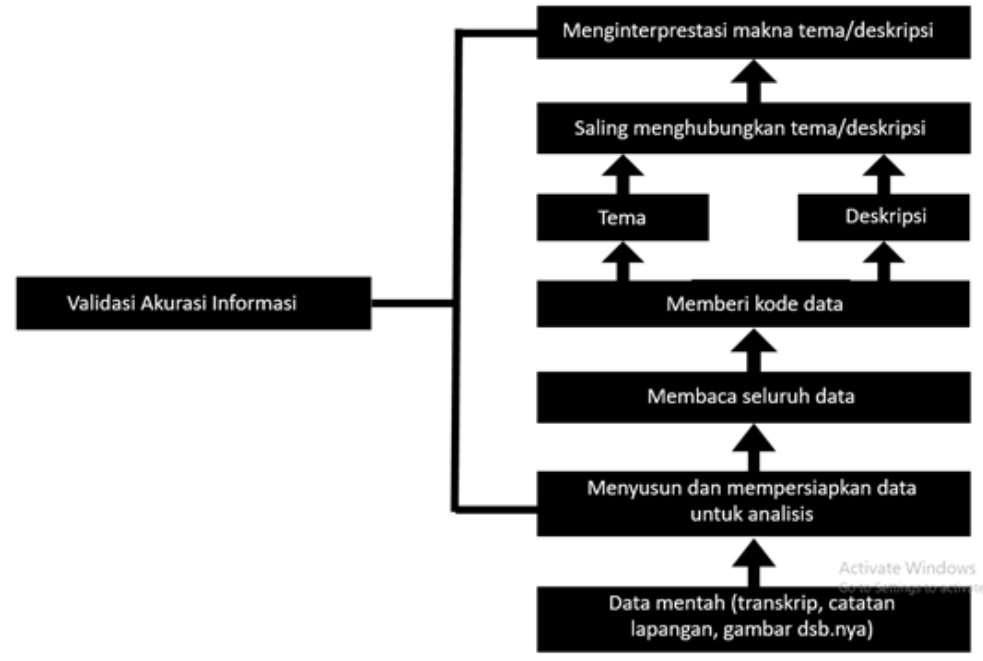

Gambar 3. Teknik Analisis Data Menurut Creswell (2015)

Sumber: Data Badan Narkotika Nasional Kota Kediri, 2019 


\section{HASIL DAN PEMBAHASAN}

Program kerja tahunan yang disusun oleh BNN Kota Kediri mengacu pada instruksi dari BNN Pusat. Walaupun berpedoman pada protokol pusat, BNN wilayah Kota atau Kebupaten diberikan wewenang untuk melakukan improvisasi asal tidak terlalu menyimpang dari protokol asli yang diberikan sebelumnya. Hal ini didasarkan pada kondisi kearifan lokal masyarakat yang berbeda tiap wilayah. Berikut ini merupakan program kerja tahunan yang di gagas oleh BNN Kota Kediri dalam menjalankan tugasnya:

\section{Sosialisasi}

Program Pencegahan, Pemberantasan Penyalahgunaan dan Peredaran Gelap Narkoba (P4GN) merupakan sebuah program yang bisa dikatakan sebagai tulang punggung dari Badan Narkotika Nasional (BNN) untuk mewujudkan masyarakat yang bersih dari pengaruh narkoba. Menurut (Sholihah, 2015) Program P4GN tersebut dicanangkan oleh pemerintah melalui BNN secara bertahap dari tahun 2011-2015. Dampak penyalahgunaan narkoba diharapkan bisa ditekan di suatu wilayah dengan tersusunnya program tersebut. Maka dari itu, melalui amanat yang tertuang dalam Peraturan Presiden Nomor 83 Tahun 2007 BNN mencoba menjadi mediator dalam terimplementasinya kegiatan tersebut pada masyarakat setempat.

Strategi sosialisasi program P4GN kepada masyarakat oleh BNN Kota Kediri dilakukan dengan berbagai cara, baik sosialisasi langsung melalui face to face seperti dengan adanya penyuluhan maupun tidak langsung dengan berbagai perantara seperti media masa. Sosialisasi ini dapat dikategorikan sebagai ujung tombak dalam tersampainya inti program P4GN kepada masyarakat secara luas. BNN Kota Kediri secara aktif memberikan sosialisasi P4GN pada seluruh jenjang pendidikan mulai dari tingkatan dasar hingga perguruan tinggi. BNN Kota Kediri juga mempunyai tim penyuluh yang ditugaskan secara khusus untuk melaksanakan program ini. Ada beberapa program yang dilakukan secara serentak maupun bergilir. Pada program serentak, biasanya hanya beberapa siswa yang mewakili sekolah masing-masing dan dilakukan pada sekolah yang telah ditentukan. Adapun pada program yang bergantian, beberapa training telah berhasil dilakukan seperti di TK Bhayangkari, SD Kristen Petra, MI Mimbaul Hakim, SMK Pawyatan Daha, SMK Perhotelan Neptune, SMK Al-Huda, SMK Pelayaran Hang Tuah, 
SMK Plus Ar-Rohmah, MAN 2 Kediri, Stikes Surya Mitra Husada, Akper/Akbid Dharmahusada, Sekolah Tinggi Agama Islam Negeri (STAIN) dan Universitas Nusantara PGRI.

Dalam berbagai kegiatan seperti saat upacara bendera, tim dari BNN Kota Kediri juga secara bergantian menyampaikan materi P4GN pada sekolah-sekolah. Berbagai even yang dilakukan sekolah pun, tidak luput dari sasaran sosialisasi. BNN secara sukses berperan dalam menyampaikan materi anti narkoba seperti dalam lomba bersih narkoba, carnaval night tematik, lomba hidup bersih dan sehat, jalan sehat, lomba dai cilik, hingga pada finalis duta genre di wilayah Kota Kediri. Menarik untuk ditindaklanjuti, BNN Kota Kediri bekerjasama dengan instansi pendidikan dan kementerian agama untuk menyusun kurikulum P4GN dalam pendidikan di Kota Kediri. Melalui kurikulum ini, para siswa baru diwajibkan mengikuti P4GN. Penanaman materi narkoba sejak dini, tentu akan sangat mendorong pola pikir siswa tersebut karena sejak di bangku sekolah diajarkan bahwa efek negatif narkoba akan mengancam karir mereka kedepannya.

Selain mengedukasi siswa, BNN Kota Kediri juga bekerjasama dengan lembaga pemerintah lainnya. Hal ini dibuktikan dengan banyaknya Lembaga pemerintah yang bersedia memberikan waktu untuk training P4GN maupun mengajukan test urine pada anggotanya. Lembaga yang sudah menjalankan program ini antara lain dinas sosial, dinas tenaga kerja (disnaker), dinas perhubungan (dishub) dan dinas komunikasi dan informasi (kominfo), komisi pemilihan umum (KPU), Polres, Brigif 16 Wira Yudha, Yonif mekanis 521 kediri, Koramil dan Kodim 0809. Lebih lanjut, sosialisasi P4GN ini juga berhasil dilaksanakan pada Satuan Kerja Perangkat Daerah (SKPD).

Kampanye anti narkoba juga dilakukan bersama dengan tokoh keagamaan se-Kota Kediri. Sebagai contoh, organisasi muslimat NU (Nahdlatul Ulama) melalui program yang dibentuk bersama BNN Kota Kediri juga aktif dalam deklarasi anti narkoba. Program ini pun berlanjut di beberapa pondok pesantren, seperti Ponpes Wali Barokah LDII, Ponpes Wahidiyah, Ponpes Darussalam maupun Ponpes Lirboyo. Program keagamaan yang di inisiasi oleh ponpes tersebut bersama dengan masyarakat sekitar seperti agenda santunan anak yatim dan kaum dhuafa juga tidak luput dari penyampaian 
materi P4GN dari tim penyuluh BNN Kota Kediri. Materi P4GN pun juga menjadi penyampaian yang rutin bagi pengurus pondok pesantren tersebut.

Tim dari BNN juga secara aktif mendatangi berbagai komunitas di masyarakat untuk diberikan penyuluhan tentang narkoba agar terhindar dari dampak buruk yang ditimbulkan. Komunitas tersebut meliputi organisasi beladiri, komunitas pecinta otomotif, remaja masjid, pusat informasi konseling remaja, komunitas waria dan berbagai organisasi masyarakat lainnya. Kegiatan yang bersifat positif di masyarakat tentu akan sangat membantu untuk menghindarkan mereka dari bahaya narkoba yang dating mengancam. Dengan dibekali protokol P4GN, diharapkan kelompok tersebut mampu menyebarkan pada anggotanya maupun keluarganya di rumah. Di samping itu, BNN juga telah membentuk satgas anti narkoba yang secara kedudukan berada dalam kendali BNN untuk melakukan pengontrolan dan sosialisasi atau membantu program kerja yang dibentuk BNN itu sendiri. Penetapan anggota satgas melalui dibentuk melalui proses seleksi. Selain membentuk satgas, BNN Kota Kediri juga membentuk lascar anti narkoba yang dibentuk dari anggota ormas dan pelajar. Lebih lanjut, BNN juga menetapkan duta anti narkoba dari kalangan pelajar di Kota Kediri.

Selain sosialisasi secara langsung, BNN Kota Kediri juga melakukan sosialisasi secara tidak langsung dengan menggunakan perangkat media cetak maupun elektronik. Melalui media cetak, materi tentang bahaya narkoba pernah diberikan melalui koran, seperti koran Jawa Pos yang juga diedarkan di wilayah Jawa Timur. Melalui media elektronik, BNN mempunyai media komunikasi berbasis media sosial yang popular seperti Instagram, Facebook dan video di Youtube. Penggunaan media sosial di yakini mampu menarik perhatian kaum milenial di era saat ini. Seperti halnya yang kita tahu saat ini, hampir semua sektor diperkuat oleh media sosial atau aplikasi berbasis android. Peluang ini pun tidak di sia-siakan oleh tim humas dalam memberikan sosialisasi secara online. Beberapa poster perayaan hari besar nasional pun di desain dengan menarik, kemudian disebar melalui medsos dan tidak lupa diberi logo anti narkoba. BNN Kota Kediri juga memiliki website yang bisa diakses dengan mudah oleh masyarakat untuk mendapat layanan secara gratis. 
Materi P4GN juga disampaikan oleh tim penyuluh kepada masyarakat secara luas melalui siaran radio dan televisi lokal. Beberapa radio yang menjadi langganan siaran tersebut adalah Radio Wijangsongko, Andika FM dan Bonansa FM. Dari sektor televisi juga berlangganan seperti KSTV, BBSTV dan Dhoho TV. Selain tayang dalam penyampaian materi, BNN Kota Kediri juga memasang spot iklan sehingga msyarakat yang terbiasa mendengarkan radio dan menonton siaran televisi dapat secara rutin di edukasi melalui iklan tersebut agar jauh dari bahaya narkoba.

BNN Kota Kediri juga mempunyai program berupa car freeday. Program tersebut berlangsung di Jalan Dhoho dan Gedung Olahraga (GOR) Jayabaya. Dibarengi dengan kegiatan berolahraga jalan santai, program yang melibatkan semua komponen masyarakat di semua golongan usia ini di ikuti dengan pemasangan logo dan bersama sama memberikan aksi perlawanan terhadap narkoba yang dikemas dengan lebih menarik untuk meningkatkan semangat masyarakat.

Mengingat kegiatan penyuluhan merupakan suatu proses komunikasi dua arah, maka selalu ada komunikator dan komunikan yang selalu berhubungan dalam suatu interaksi. Di satu pihak, komunikator harus beusaha mempengaruhi komunikan agar terjadi perubahan pengetahuan dari tidak tahu menjadi tahu dan dari tidak mengerti menjadi mengerti serta diharapkan terjadi perubahan tindakan dan perilaku. Tentu hal ini sangat dipengaruhi oleh dengan siapa penyuluhan itu dilakukan. Berbeda target, tentu berbeda pendekatan yang dilakukan (Kaddi, 2014) Menurut (Hardianto, 2014) ada beberapa faktor yang mendukung keberhasikan program sosialisasi yang dilakukan oleh sebuah lembaga, yakni meliputi faktor komunikasi, faktor institusi dan faktor partisipasi. Oleh karena itu, penyampaian materi oleh BNN Kota Kediri juga selalu disesuaikan berdasarkan kebutuhan seperti tingkatan usia maupun tingkatan pendidikan sehingga komunikasi yang dibangun dua arah bisa ber jalan maksimal. Sementara itu, kreatifitas juga harus terus dikembangkan untuk meningkatkan daya tarik dari partisipan.

(Sholihah, 2015) melakukan investigasi terhadap pekerja di Kota Banjarmasin setelah dilakukan sosialisasi P4GN dari tim penyuluh BNN setempat. Hasil menunjukkan bahwa para pekerja mengalami perubahan pengetahuan tentang narkotika dan bahayanya. Hal ini membuktikan adanya efektivitas dalam memberikan edukasi melalui sosialisasi. 
Berdasarkan studi yang lain (Aini, 2018) sosialisasi di lingkungan pelajar di Kota Mataram juga berdampak bagi meningkatnya pengetahuan siswa akan bahaya narkoba. Walaupun demikian, masih banyak ditemukan kendala seperti kurangnya pendanaan, sumberdaya manusia, bimbingan secara teknis dan operasional. (Lilis \& Lestari, 2017) mengkalkulasikan sebanyak 78\% responden di kalangan pelajar Kota Jogjakarta mengerti dengan baik dan memahami materi P4GN yang di sosialisasikan.

(Sholehudin, 2019) mengemukakan bahwa platform andoid di zaman modern ini berperan penting dalam edukasi anti narkoba yang dilakukan oleh BNN. Lebih dari itu, masyarakat juga bisa melakukan pengaduan langsung secara online sehingga mampu berperan dalam memetakan wilayah rawan narkoba. Penulis memberikan analisis bahwa BNN di Kota Kediri dalam melakukan sosialisasi tidak menemukan banyak kesulitan. Penulis pun mencoba untuk membandingkan hasil penelitian ini dengan temuan lainnya yang ada di wilayah lain terkait sosialisasi. Adanya hambatan di daerah lain pun ditemukan, seperti halnya di Provinsi Jawa Tengah. Ditulis oleh (Oktavio \& Winjaya, 2020), BNN di wilayah tersebut mengeluhkan kurangnya kesadaran masyarakat terhadap bahaya menggunakan narkoba. Walaupun BNN sudah berusaha keras untuk mengkampanyekan bahaya narkoba, adanya kondisi mental anak yang berbeda dan perbedaan kemampuan seorang anak dalam mengambil keputusan yang benar masih menjadi kendala dalam upaya sosialisasi kepada anak. Kemudian, banyak hambatan pula yang ditemui dalam mengembalikan korban kepada masyarakat seperti akibat adanya asumsi masyaratkat yang buruk kepada penyalahguna narkotika. BNN juga kesulitan memonitoring sebagian besar anak karena tersebar di wilayah Indonesia yang luas dengan jumlah penduduk Indonesia yang berbanding terbalik dengan jumlah petugas dari BNN itu sendiri. BNN sudah melakukan sosialisasi sejak dini dari ibu-ibu yang sedang mengandung anak nya agar kelak orang tua dapat membimbing anak-anak mereka untuk dapat terhindar dari jeratan narkoba kerana anak merupakan aset yang sangat beharga bagi bangsa maupun orang tua.

Tidak hanya di Provinsi Jawa Tengah, hambatan sosialisasi juga ditemukan di wilayah lainnya, yakni di Provinsi Aceh. (Habibi, 2019) menuturkan bahwa ada masalah komunikasi yang menjadi kendala. Hal ini karena kurangnnya kerjasama masyarakat 
dalam membantu BNNK memberikan data para pengguna narkotika ditempat tinggalnya dan dalam kerjasama lainnya, dikarenakan masyarakat atau keluarga korban takut jika pengguna narkoba akan dipenjarakan. Solusi yang ditetapkan oleh BNNK Banda Aceh adalah dengan memberikan penyuluhan dan informasi kepada masyarakat bahwa pengguna narkoba tidak dipenjara tetapi akan dilakukan proses rehabilitasi serta dibina agar meninggalkan barang haram tersebut. BNNK Banda Aceh memberantas penyalahgunaan narkotika dengan mempererat kerja sama dengan masyarakat agar masyarakat lebih dekat dengan BNNK. Hambatan lain yaitu sosialisasi tidak efektif karena masyarakat tidak serius dalam memahami dan melakukan tindakan untuk solusi yang didesain oleh BNNK. Untuk mengatasinya, BNNK mempermudah bahasa dan teknik sosialisasi yang membuat masyakat cepat tanggap dan mudah menerima pesan yang disampaikan BNNK. Keberhasilan yang telah dicapai oleh pihak BNNK Banda Aceh dalam sosisalisasi adalah menstimuluskan para audiens (pendengar) yang memberikan dampak lebih merespon terhadap apa yang telah disampaikan. Keberhasilan lain yaitu terjalinnya kerjasama antara BNNK Banda Aceh dengan masyarakat seperti membentuk organisasi di dalam masyarakat khususnya para pemuda demi memberantas narkotika. Kerjasama lainnya yaitu berupa lembaga pemerintahan dan lembaga pendidikan untuk bekerja secara sama-sama dalam memberantas narkoba di Kota Banda Aceh, meskipun belum menurunkan jumlah pengguna narkotika, namun diharapkan dengan kerjasama tersebut dapat lebih memperluas lagi koneksi BNNK dalam memberantas narkotika.

BNN pun semakin aktif dengan memberikan inovasi dalam kegiatan sosialisasi yang dilakukan. Namun, hal ini pun tidak luput dari adanya hambatan. Berdasarkan laporan oleh (Pratiwi, 2018) BNN Provinsi Lampung membuat system edukatif untuk para remaja untuk menanggulangi dampak penyalahgunaan narkoba. Namun demikian, masih ada sejumlah hambatan yang dijumpai. Hambatan yang dihadapi oleh Badan Narkotika Nasional dalam melakukan upaya penanggulangan penyalahgunaan Narkotika di kalangan remaja ialah dari segi penegakan hukum, dari segi fasilitas yang kurang memadai, dan penyampaian materi-materi kepada setiap sekolah dan kampus yang masih kurang merata kualitasnya. 
BNN di Kota Malang pun juga menemui kendala dalam melakukan kegiatan sosialisasi. Hambatan yang dialami BNN dalam pengendalian sosial mencegah penyalah gunaan narkotika di terdiri dari dua bentuk yaitu hambatan internal dan hambatan eksternal. Solusi yang dilakukan BNN Kota Malang dalam mengatasi hambatan yang dialami yaitu dengan melakukan koordinasi dengan instansi lain, memaksimalkan fasilitas yang ada dan pemanfaatan sarana pribadi, memaksimalkan anggaran yang ada dan Lebih memperkenalkan BNN (Alkaf, 2016).

\section{Pencegahan}

Secara umum, sosialisasi juga dapat dikelompokkan sebagai salah satu upaya dalam mencegah penyalahgunaan narkoba sejak dini dengan melakukan edukasi berupa materi P4GN seperti di jelaskan dalam poin sebelumnya. Namun, disamping itu ada beberapa program lainnya dari BNN Kota Kediri sebagai upaya pencegahan, diantaranya pembentukan kelurahan bersinar, pembinaan masyarakat hingga tes urine bagi pelamar pekerjaan maupun lanjut studi ke jejang yang lebih tinggi. Kelurahan Bersinar (Bersih dari Narkoba) merupakan program yang dibentuk oleh BNN Kota Kediri pada tingkat kelurahan. Pemberian gelar pada kelurahan yang dipilih sebagai kelurahan bersinar merupakan salah satu ajang bergengsi di wilayah Kota Kediri. Pertimbangan utama selain bahwa masyarakat yang tinggal di dalamnya tidak tersangkut kasus narkoba, yakni respon masyarakat yang tinggi terhadap penolakan segala bentuk narkoba. Masyarakat yang responsive baik dari tokoh dan warganya adalah kunci keberhasilan advokasi oleh tim dari BNN kepada mereka. Pada Tahun 2019 ini, Kelurahan Ngronggo terpilih sebagai kelurahan bersinar. Ngronggo merupakan kawasan padat penduduk di barengi dengan kondisi masyarakat yang di kelilingi oleh area pendidikan favorit, seperti MTsN 2 Kota Kediri dan Institut Agama Islam Negeri (IAIN). Selain itu, di Kawasan tersebut terdapat pasar grosir yang cukup besar, sehingga kegiatan jual beli masyarakat akan dapat termonitoring dan terhindar dari kerawanan transaksi narkoba dengan adanya program kelurahan bersinar yang diperoleh oleh Kelurahan Ngronggo dalam setahun kedepan.

BNN Kota Kediri juga melakukan pembinaan kepada masyarakat seperti Program Keluarga Sadar Hukum (Kadarkum). Program ini berfungsi untuk menghimpun warga dengan kemampuannya untuk memahami hak dan kewajiban sebagai warga negara yang 
diatur oleh hukum berdasarkan perundang-undangan yang berlaku seperti larangan penggunaan narkoba. Program ini telah terlaksana di beberapa kelurahan, salah satunya kelurahan betet. Program Kadarkum ini juga ditingkatkan melalui diadakanya berbagai lomba. Saat ini, tes urine menjadi salah satu program yang dinilai mampu menimbulkan rasa takut bagi masyarakat untuk mengkonsumsi narkoba. Tes urine telah menjadi kewajiban untuk mengikuti berbagai macam seleksi yang diselenggarakan oleh instansi tertentu baik untuk masuk pekerjaan atau melanjutkan ke pendidikan yang lebih tinggi. Tercatat bahwa instansi milik pemerintah seperti pendaftaran CPNS, BUMN, kepolisian dan tentara memasukkan hasil tes urine sebagai persyaratan yang tidak boleh tertinggal. Selain sebagai persyaratan mendaftar, hasil tes ini juga rutin dilakukan sebagai bentuk monitoring anggota instansi agar tidak terlibat dalam urusan narkoba. Hasil tes urin diterbitkan sebagai SKHPN (Surat Keterangan Hasil Pemeriksaan Narkotika).

BNN Kota Kediri dinilai berhasil dalam menekan angka pelapor penyalahgunaan narkoba dalam kurun waktu 5 tahun terakhir. Selain itu, ada indikasi kesadaran masyarakat mulai meningkat. Tersampainya informasi melalui sosialisasi akan mendorong pengetahuan masyarakat terkait bahaya narkoba (Hanifah \& Unayah, 2011). Keberhasilan tersebut juga terlihat dari semakin tingkat wawasan masyarakat akan pentingnya menjaga kesehatan.

Menurut (Adam, 2012) pencegahan penyalahgunaan narkoba tergolong dalam intervensi primer yakni ketika sebelum penyalahgunaan terjadi yang biasanya dalam bentuk pendidikan, penyebaran informasi mengenai bahaya narkotika, pendekatan melalui keluarga, dan lain-lain. Instansi pemerintah lebih banyak berperan pada tahap intervensi ini. Kegiatan dilakukan seputar pemberian informasi melalui berbagai bentuk materi yang ditujukan kepada orang secara langsung dan keluarga.

Program parenting dari BNN juga mengantisipasi sejak dini bahwa kita dilarang mencoba-coba. Sekali mencoba maka besar keungkinan akan ketagihan dan berpengaruh buruk bagi masa depan. Berdasarkan literatur dari (Indonesia, 2007) para orang tua perlu membekali diri dengan pengetahuan tentang jenis-jenis narkoba dan bahaya yang memungkinkan mendatangi anak-anak mereka dengan berbagai cara. Orang tua harus waspada dengan tanda-tanda pada anak yang rentan terhadap godaan narkoba. Sikap anak 
perlu dimonitor dengan bijak agar mereka merasa nyaman tetapi aman dari gangguan penyalahgunaan narkoba.

Peneliti juga melakukan perbandingan dengan kendala yang dijumpai di daerah lainnya seperti dalam ruang lingkup pencegahan. Tidak seperti Kota Kediri yang lebih tanggap dalam melakukan pencegahan dengan cara pendekatan kepada masyarakat setempat, (Muzakkir, 2019) mengungkapkan bahwa di Kabupaten Donggala, Sulawesi Tengah ditemukan banyak kendala yang ditemui pihak BNN. Faktor-faktor yang mempengaruhi efektivitas pelaksanaan kinerja Badan Narkotika Nasional (BNN) Kabupaten tersebut dalam upaya pencegahan dan pemberantasan penyalahgunaan narkotika, psikotropika dan zat adiktif lainnya di wilayah hukum dapat ditinjau dari faktor hukum, faktor penegak hukum, faktor sarana dan fasilitas dalam penegakan hukum, faktor masyarakat dan faktor kebudayaan. Undang-undang No. 35 tahun 2009 di dalam praktiknya sangat lambat terutama dalam penyesuaiannya dengan perkembangan di dalam masyarakat setempat sehingga substansi undang-undang tersebut tidak responsif lagi terhadap jenis narkotika, psikotropika dan zat adiktif yang cenderung sebelumnya tidak tercantum. Jika ditinjau dari segi kuantitas petugas BNN Kabupaten Donggala masih jauh dari ideal, dibarengi dengan masih minimnya dana program kegiatan yang juga menyebabkan jumlah pelaksanaan kegiatan tidak efektif. Disisi lain terdapat sikap masyarakat yang takut memberikan informasi adanya penyalahgunaan narkotika, psikotropika dan zat adiktif dilingkungan keluarga, walaupun mereka akan memperoleh perlindungan hukum dan adanya pemahaman masyarakat yang masih lemah khususnya generasi muda terhadap jenis narkotika, psikotropika dan zat adiktif serta dampak yang ditimbulkan.

\section{Pemberantasan}

Berikut ini merupakan hasil pemberantasan gelap peredaran narkoba yang berhasil diungkap oleh BNN Kota Kediri dalam kurun waktu 5 tahun terakhir: 


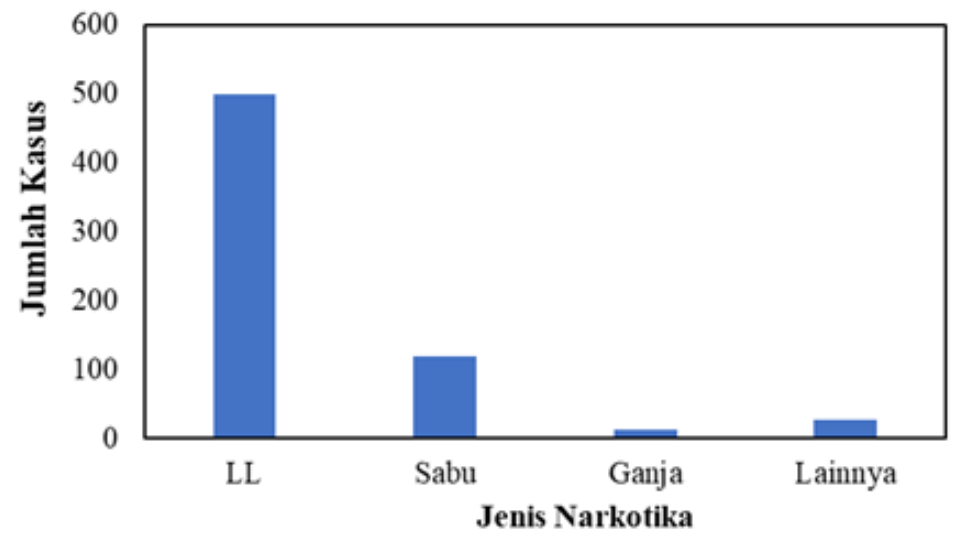

Gambar 5. Jumlah Kasus Berdasarkan Jenis Narkoba yang Digunakan Sumber: Data Badan Narkotika Nasional Kota Kediri, 2019

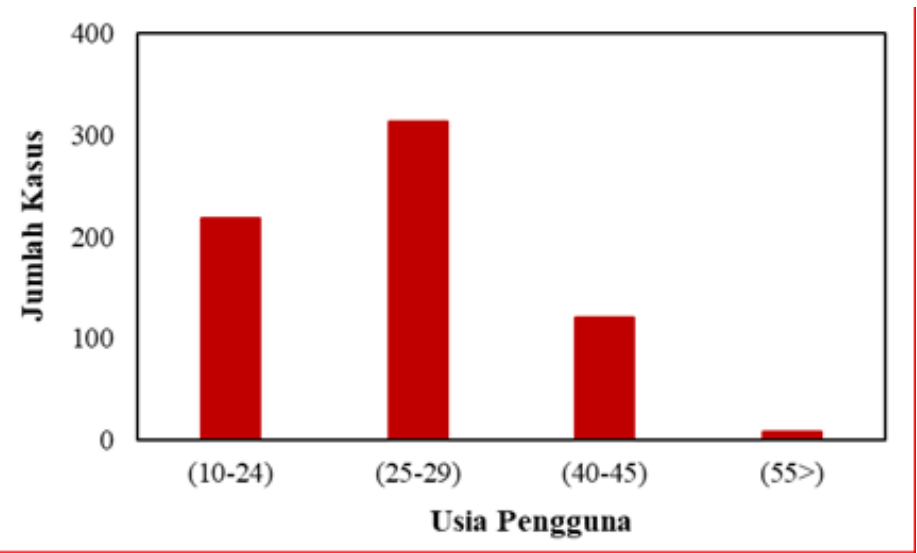

Gambar 6. Jumlah Kasus Berdasarkan Rentang Usia Pengguna Sumber: Data Badan Narkotika Nasional Kota Kediri, 2019

Kasus penyalahgunaan narkoba di wilayah Kota Kediri di dominasi oleh konsumsi LL sebanyak 500 kasus, diikuti oleh sabu sebanyak 120 kasus. Sementara itu, ganja disalahgunaan sebanyak 12 kasus sedangkan sisanya adalah narkotika campuran sebanyak 27 kasus. Kasus terbanyak dilaporkan dilakukan dalam kategori umur pemuda (25-29 tahun) dengan jumlah total 313 kasus. Para remaja (10-24 tahun) menduduki peringkat kedua dengan angka 218 kasus. Posisi selanjutnya di isi oleh kategori dewasa (40-45 tahun) dengan jumlah 120 kasus. Sementara lanjut usia (diatas 55 tahun) reatif sedikit dengan kasus sebanyak 8 . 
Dalam aspek pemberantasan, BNN Kota Kediri bekerjasama dengan polres Kota Kediri dalam melakukan investigasi untuk memetakan daerah rawan narkoba. Faktor yang menjadi acuan antara lain:

(1) Bagaimana tingkat kasus kejahatan narkotikanya,

(2) Angka kriminalitas,

(3) Aksi kekerasan,

(4) Adanya bandar,

(5) Adanya tempat produksi,

(6) Angka pengguna narkotika yang lebih banyak,

(7) Adanya barang bukti dan

(8) Adanya kurir yang terlibat.

Meninjau program yang lain, BNN Kota Kediri juga bekerjasama dengan Bea Cukai dan Kantor Pos untuk melakukan penggeledahan barang yang terindikasi narkotika. Dalam hal ini, barang yang di selundupkan berasal dari luar negeri. Pada umumnya, bea cukai yang menelusuri pengiriman dari luar negeri tersebut. Berdasarkan temuan BNN, sebagian besar barang narkotika di selundupkan melalui kapal kemudian di dalam negeri di distribusikan lewat kantor pos. BNN Kota Kediri juga secara aktif bekerjasama dengan Polres Kota Kediri untuk melakukan penangkapan terhadap pelaku penyalahgunaan dan pengedar narkoba.

Usia remaja dan usia muda menjadi sangat rawan dalam kasus penyalahgunaan narkoba. Pada usia muda, ego dan pola pikir masih belum stabil dan mudah dihasut oleh rekan-rekannya untuk menggunakan narkoba. Menggunakan barang haram tersebut dinilai mampu menghilangkan stress. Menurut (Simangunsong, 2015), faktor pergaulan dengan teman sebaya yang terlalu bebas dan tidak terkontrol menyebabkan remaja ikut terjerumus melakukan penyalahgunaan narkoba narkoba. Agar remaja tidak terjerumus dalam penyalahgunaan narkoba peran serta orang tua sangat dibutuhkan dengan lebih meningkatkan pengawasan terhadap perilaku anggota keluarganya, para orang tua juga diharapkan untuk selalu meluangkan waktunya untuk selalu berada disisi anak-anaknya dalam kondisi apapun, sehingga remaja tidak terjerumus melakukan hal-hal yang menyimpang terutama melakukan penyalahgunaan narkoba. Selain itu perlu adanya 
kerjasama yang baik oleh semua elemen baik pemerintah maupun masyarakat sehingga penyalahgunaan narkoba dikalangan remaja dapat dicegah sedini mungkin.

Pada usia dewasa, banyak ditemui kasus pengguna narkoba berasal dari kalangan sopir, tukang angkat, kuli, hingga penambang pasir. Persepsi yang salah dari fungsi narkoba untuk menambah stamina penambang menjadi alasan kuat penyebaran penyalahgunaan narkoba dari jenis pekerjaan ini. Di Kota Semarang juga ditemukan kasus yang serupa dengan modus sebagai penghilang rasa kantuk (Primamrenalto, 2016) Kemiripan kasus ini juga terjadi di Kota Jepara dimana banyak kuli bekerja di area wisata menggunakan narkoba (Mashudi, 2013).

Temuan narkoba di Kota Kediri sebagian besar disuplai dari luar negeri. (Puspitosari \& MH, 2013) melaporkan bahwa sebanyak 60 - 70 persen narkotika yang beredar di Indonesia berasal dari luar negeri sedangkan 30 - 40 persen lainnya di produksi di dalam negeri. Namun, berbeda dengan temuan (Andriyani, 2011) bahwa justru narkoba yang di produksi Indonesia belakangan ini menjadi primadona yang diproduksi secara tertutup dan pabriknya ditemukan di perumahan pribadi. Saat ini, Asia merupakan produsen terbesar narkotika di dunia (Pamungkas et al., 2017) Beberapa kasus ditemukan narkoba dalam bentuk gula dan permen untuk diberikan pada kalangan anak-anak (Andriyani, 2011).

Terkait dengan upaya penegakan hukum yang dilakukan oleh BNN, dalam studinya di pulau dewata bali, (Suparta, 2015) memberikan hasil informasi pentingnya upaya preventif dan upaya represif agar dilakukan. Upaya preventif meliputi adanya rapat koordinasi tim interdiksi, memasang sepanduk dengan berbahasa asing ditempat -tempat keramaian, dihotel dan direstoran maupun ditempat umum lainnya, melakukan kordinasi kepada masyarakat, melakukan kordinasi kepada beacukai, menyelenggarakan program kerjasama dalam rangka P4GN, melakukan kordinasi dengan migrasi. Sementara itu, upaya represif meliputi pengamanan barang bukti dan pengamanan terhadap pelaku penyalahgunan narkotika dan penindakan terhadap pelaku yang terbukti melakukan penyalahgunaan narkotika.

Di daerah kota atau provinsi lain BNN juga mengalami beberapa hambatan dalam memberantas, sebagai contoh adalah upaya BNN dari Bali yang dilaporkan oleh (Suparta, 
2015). BNN di wilayah tersebut menemui hambatan manakala ingin menanggulangi tindak pidana penyalahgunaan narkotika terutama yang dilakukan oleh warga asing. Hambatan yang ditemui yakni terjadi penolakan dari pemilik hotel dan restoran untuk dipasang spanduk atau stiker oleh BNN. Kemudian, BNN jarang bisa mengungkap kasus secara menyeluruh di Kawasan tersebut akibat akses yang terbatas.

Hambatan dari segi rehabilitasi juga dikaji oleh (Raida et al., 2018) dengan tema penelitian terhadap kendala dari BNN Provinsi Aceh. Menurutnya, BNN mempunyai pekerjaan yang sulit akibat pecandu sudah mengalami kondisi akut, sarana dan prasaran yang kurang memadai, serta ketakutan akan pandangan dari pihak kepolisian yang masih menerapkan pidana penjara bagi pecandu narkotika. Konselor adiksi pun terlihat belum mempunyai keterampilan atau pengetahuan mumpuni terkait dengan teori konseling, sehingga belum mampu menanakan kepercayaan bagi orang tua pihak klien. Kendala tersebut meliputi adanya perilaku klien seperti susah membuka diri, sebuah perilaku yang selit diubah karena masih dalam efek kecanduan narkoba. Dari faktor keluarga, dukungan orang tua yang kurang baik ditambah dengan persepsi orang tua terhadap konselor adiksi yang juga kurang baik. Masyarakat pun berpandangan bahwa klien merupakan orang yang sudah terjerumus dan tidak perlu dikasihani. Selain itu, peneliti juga menemukan adanya kondisi yang kurang baik dari tempat rehabilitasi.

\section{Hambatan BNN Dalam Menjalankan Tugas}

Dalam internal BNN, belum ditemukan adanya hambatan yang sifatnya krusial. Tantangan yang ditemukan biasanya adalah mengelola anggaran yang ditetapkan oleh Pemerintah Pusat agar cukup untuk mengelola program yang telah disusun sebelumnya juga dan ada juga kurangnya SDM, karena SDM masih belum ideal. Selain itu, diperlukan komitmen yang kuat dari para pimpinan dan anggota dalam mengemban amanah yang telah diberikan. Dari segi eksternal, ada pesan moral yang tersampaikan dimana BNN menangkap warga sendiri yang menjadi penyalahguna narkoba. Sebagaimana disampaikan sebelumnya bahwa narkoba tersebut mayoritas berasal dari luar negeri yang sengaja dikirim ke Indonesia demi keuntungan dan kepentingan segelintir orang dan mengorbankan masyarakat lokal. Hambatan yang lain karena masyarakat kurang sadar 
akan bahayanya narkoba atau masyarakat kurang memahami tugas BNN tersebut sehingga orang seperti itu rentan untuk menyalahgunakan narkoba tersebut.

Penulis pun memberikan pendapat bahwa BNN Kota Kediri pada dasarnya bekerja dengan baik dengan dibuktikannya fakta bahwa BNN tidak menemui banyak kendala saat menjalankan tugasnya. Hal ini juga diperkuat dengan fakta lain dari berbagai karya tulis yang telah dipelajari penulis itu sendiri bahwa BNN dari wilayah lain menemui kendala dari berbagai aspek.

Berkaca dari banyaknya hambatan yang ditemui oleh berbagai BNN yang tersebar dari pusat dan wilayah lainnya di Indonesia, peneliti memberikan apresiasi yang tinggi bagi kinerja BNN Kota Kediri yang mampu bekerjasama secara baik antar masing-masing elemen didalamnya. BNN juga bekerjasama dengan baik dengan berbagai instansi yang ada di Kota Kediri. Penulis pun memberikan argumen pada dasarnya warga di Kota Kediri juga tidak acuh terhadap narkoba yang dibuktikan dengan banyaknya request berbagai komunitas dan instansi agar BNN datang dan memberikan sosialisasi. Walaupun pada dasarnya peneliti juga meragukan tentang apakah BNN pada dasarnya benar-benar memberikan sosialisasi secara merata ke seluruh wilayah dan masyarakat karena pasti secara pendanaan dan jumlah tenaga yang terbatas. Narkoba merupakan ancaman bersama, walaupun secara undang-undang merupakan tugas dan wewenang dari BNN, masyarakat juga harus secara gotong-royong membantu satu sama lainnya seperti tercermin dalam ideologi Pancasila yang dianut negeri ini. Bersama kita bisa terbebas dari pengaruh buruk terhadap narkoba ini.

\section{KESIMPULAN DAN SARAN}

Berdasarkan hasil penelitian dan pembahasan sebagaimana dijelaskan pada bab terdahulu, maka dapatlah ditarik kesimpulan sebagai berikut: Upaya BNN Kota Kediri dalam menanggulangi penyalahgunaan narkoba dilakukan dengan cara diadakannya sosialiasi yang dilakukan dengan memberikan materi Pemberantasan Penyalahgunaan dan Peredaran Gelap Narkoba (P4GN) pada pelajar pekerja dan berbagai kelompok masyarakat serta menyampaikannya pada acara radio maupun televisi lokal setempat, 
Pencegahan dengan membentuk kelurahan bersih narkoba (bersinar) dan penerbitan Surat Keterangan Hasil Pemeriksaan Narkotika (SKHPN) merupakan program dari upaya pencegahan dan pemberantasan berupa penggeledahan barang terduga narkotika serta menangkap para pelakunya. Faktor penghambat upaya BNN Kota Kediri dalam menanggulangi penyalahgunaan narkoba dalam menjalankan tugasnya yang ditemui hanya seputar tantangan mengelola anggaran, kurangnya SDM dan beban moral, karena menangkap warga sendiri yang terlibat narkoba. Sedangkan penulis memberikan saran berupa penekanan sosialisasi P4GN pada wilayah yang rawan peredaran dan penyalahgunaan narkoba yang telah dipetakan sebelumnya. Pembuatan video dan poster menarik juga harus lebih banyak di gencarkan di media sosial yang merupakan basis komunikasi terbesar saat ini.

\section{REFERENSI}

Adam, S. 2012. Dampak narkotika pada psikologi dan kesehatan masyarakat. Jurnal Health and Sport, 5(2).

Aini, Q. 2018. Dampak sosialisasi pencegahan narkoba oleh badan narkotika nasional (BNN) kota Mataram terhadap peningkatan kesadaran siswa kelas XI MA Nurul Jannah NW Ampenan Tahun Pelajaran 2016/2017. Universitas Islam Negeri Mataram.

Alkaf, M. K. 2016. Pengendalian sosial Badan Narkotika Nasional dalam upaya mewujudkan Kota Malang bebas dari penyalahgunaan narkotika. Universitas Negeri Malang.

Andriyani, T. 2011. Upaya Pencegahan Tindak Penyalahgunaan Narkoba di Kalangan Mahasiswa Politeknik Negeri Sriwijaya. Jurnal Ilmiah Orasi Bisnis-ISSN, 2085, 1375.

Felicia, E. 2015. Kendala dan Upaya Rehabilitasi Bagi Pecandu Narkotika oleh Badan Narkotika Nasional Provinsi (BNNP) Yogyakarta. Skripsi. Yogyakarta: Fakultas Hukum, Universitas Atmajaya Yogyakarta.

Habibi, H. 2019. Hambatan Komunikasi Badan Narkotika Nasional Kota Banda Aceh dalam Menanggulangi Penyalahgunaan Narkoba. UIN Ar-Raniry Banda Aceh.

Hanifah, A., \& Unayah, N. 2011. Mencegah dan menanggulangi penyalahgunaan napza Melalui peran serta masyarakat. Sosio Informa, 16(1). 
Hardianto, A. 2014. Studi Deskriptif Tentang Perubahan Paradigma Sosialisasi Program Keluarga Berencana Berkelanjutan Di Kabupaten Bojonegoro. Universitas Airlangga.

Indonesia, B. N. N. R. 2007. Pencegahan Penyalahgunaan Narkoba Sejak Usia Dini. Jakarta: BNN.

Kaddi, S. M. 2014. Strategi Penyuluhan Kesehatan Masyarakat Dalam Menanggulangi Bahaya Narkoba di Kabupaten Bone. Academica, 6(1).

Laksono, E. T. 2015. Upaya Penanggulangan Peredaran Dan Penyalahgunaan Narkotika Di Wilayah Pedesaan (Studi di Badan Narkotika Nasional Kabupaten Kediri dan Satuan Reserse Narkoba Kepolisian Resort Kediri). Kumpulan Jurnal Mahasiswa Fakultas Hukum, 4(2).

Leksana, I. 2013. Upaya Badan Narkotika Nasional Dalam Menanggulangi Penyalahgunaan Variasi Tanaman \& Zat Yang Mengandung Efek Narkotika (Studi Kasus Di Kantor Badan Narkotika Nasional Kota Malang). Universitas Brawijaya.

Lilis, L., \& Lestari, S. 2017. Pengaruh Pelaksanaan Sosialisasi P4gn Terhadap Tingkat Pengetahuan Tentang Napza Di Smp Muhammadiyah 8 Yogyakarta. Universitas' Aisyiyah Yogyakarta.

Mashudi, M. 2013. Penguatan Peran Lembaga Keagamaan Di Kawasan Wisata Kuliner Pantai Pungkruk Mororejo Mlonggo Jepara Dalam Pencegahan Hiv/Aids Dan Penyalahgunaan Narkoba. Dimas: Jurnal Pemikiran Agama Untuk Pemberdayaan, 13(2), 269-290.

Menthan, F. 2013. Peranan Badan Narkotika Nasional Kota Samarinda dalam Penanggulangan Masalah Narkoba di Kalangan Remaja Kota Samarinda. Ejournal Administrasi Negara, 1(2), 544-557.

MUZAKKIR, K. 2019. Efektifitas Badan Narkotika Nasional (Bnn) Kabupaten Donggala Dalam Melakukan Upaya Penanggulangan Penyalahgunaan Narkotika. Universitas Tadulako.

Oktavio, D. B., \& Winjaya, A. 2020. Peranan Bnn Dalam Penanggulangan Tindak Pidana Narkotika Golongan 1 Yang Dilakukan Oleh Anak (Studi Kasus Di Bnnp Jawa Tengah). Prosiding Konferensi Ilmiah Mahasiswa Unissula (KIMU) Klaster Hukum.

Pamungkas, A. P., Windiani, R., \& Farabi, N. 2017. 12. Peran ASEANAPOL dalam Pemberantasan Peredaran Narkoba di Indonesia. Journal of International Relations, 3(2), 91-99. 
Pratiwi, N. W. I. 2018. Upaya Badan Narkotika Nasional (Bnn) Dalam Penanggulangan Bahaya Narkotika Dikalangan Remaja Dengan Sistem Edukatif. Fakultas Hukum UNISSULA.

Primamrenalto, D. 2016. Meditasi Żikir Untuk Meningkatkan Kesehatan Mental Pada Mantan Pecandu Narkoba Di Kecamatan Semarang Barat. UIN Walisongo.

Puspitosari, S. H., \& MH, H. 2013. Globalisasi Peredaran Narkoba. Seminar Narkoba 2013.

Raida, S., Husen, M., \& Martunis, M. 2018. Layanan Konseling dalam Proses Rehabilitasi Narkoba di Badan Narkotika Nasional (BNN) Provinsi Aceh. JIMBK: Jurnal Ilmiah Mahasiswa Bimbingan \& Konseling, 3(4).

Sholehudin, I. 2019. Pembangunan Aplikasi Chatbot Untuk Edukasi Dan Pengaduan Narkotika Dengan Memanfaatkan Dialogflow Dan Gps Pada Platform Android. Universitas Komputer Indonesia.

Sholihah, Q. 2015. Efektivitas program p4gn terhadap pencegahan penyalahgunaan NAPZA. KEMAS: Jurnal Kesehatan Masyarakat, 10(2), 153-159.

Simangunsong, J. 2015. Penyalahgunaan Narkoba Di Kalangan Remaja (Studi kasus pada Badan Narkotika Nasional Kota Tanjungpinang). Program Studi Ilmu SosiologiFakultas Ilmu Sosial Dan PolitikUniversitas Maritim Raja Ali Haji Tanjungpinang.(E-Journal) Http://Hukum. Studentjournal. Ub. Ac. Id (Di Akses Pada 20.

Sinaga, A. P. 2019. Tinjauan Yuridis Permufakatan Jahat Penyalahgunaan Narkotika Berdasarkan Undang-Undang Nomor 35 Tahun 2009 Tentang Narkotika (Studi Putusan Nomor: 423/Pid. sus/2018/PN. Mdn). Universitas Medan Area.

Strauss, A., \& Corbin, J. 2003. Penelitian Kualitatif. Yogyakarta: Pustaka Pelajar.

Sugiono, S. (2016). Metode Penelitian Kuantitatif, Kualitatif, dan $R$ \& D. Bandung: Alfabeta.

Suparta, I. K. 2015. Upaya Badan Narkotika Nasional (Bnn) dalam Menanggulangi Tindak Pidana Penyelundupan Narkotika oleh Warga Negara Asing (Study di Badan Narkotika Nasional Provinsi Bali). Kumpulan Jurnal Mahasiswa Fakultas Hukum.

Undang-Undang No. 35 Tahun 2009

Undang-Undang (UU) Nomor 22 Tahun 1997 